\title{
METHOD FOR INCREASING THE CAPACITY OF THE EMERGENCY RESPONSE SYSTEM
}

Mohammed Omar Ahmed Abdulvasea, Taiz University, Taiz, Republic of Yemen omaralmu20I2@mail.ru
Keywords: Emergency mode, Emergency services, Interactive voice menu, call centers, throughput

Information about author:

Mohammed Omar Ahmed Abdulvasea, Taiz University, Taiz, Republic of Yemen, Graduate student of the Department of Communication Networks and Switching Systems MTUCI

\begin{abstract}
The main entry point for all appeals in emergencies is an emergency call center. General requirement - quick and reliable processing of citizens appeals. The operator system of call centers is designed for a certain average level of traffic. A sharp increase in the number of calls in emergencies reduces the availability of operators. Only a small portion of calls will be served by operators. A significant part of calls are routed to the interactive voice menu system IVR. Important messages about emergencies may be missed. When developing a mathematical model and studying the characteristics of complex communication systems in the theory of teletraffic, decomposition of such systems as sets of individual modules is used. Calculation of the characteristics of the studied system is carried out using the characteristics of individual modules. Using this approach facilitates the input and analysis of various generalizations of the main model. Algorithms for evaluating characteristics at two levels of the general model can be produced independently of each other, making the necessary changes. The article discusses options for creating a mutual assistance system for the timely receipt of reliable information from users. The results of analytical calculations are confirmed by the results of mathematical modeling.
\end{abstract}

\footnotetext{
Для цитирования:

Мохаммед О.А.А. Метод повышения пропускной способности системы реагирования на экстренные ситуации // Т-Сотт: Телекоммуникации и транспорт. 2020. Том I4. №5. С. 62-68.

For citation:

Mohammed Omar Ahmed Abdulvasea (2020) Method for increasing the capacity of the emergency response system. T-Comm, vol. I4, no.5, pp. 62-68. (in Russian)
} 
You can reduce the burden on emergency operators in the emergency zone by sending part of the service calls to other emergency call service centers (CSC) of the mutual assistance system $[1,2]$. When developing a mathematical model and studying the characteristics of complex communication systems in the theory of teletraffic, decomposition of such systems as sets of individual modules is used. Calculation of the characteristics of the studied system is carried out using the characteristics of individual modules $[3,4,5]$.

In relation to the entire set of call centers, united in a mutual assistance system, we use the concepts of "macro level" and "micro level". The concept of "macro level" is introduced to describe the interaction between each of the emergency call centers (CSC) and a similar center in the emergency zone (CSCEmerge). Characteristics related to the macro level are the characteristics of each of the call centers taking into account the service processes in CSC-Emerge. The characteristics related to the micro level are the characteristics of the call center - emergency, as a separate object of research.

Using this approach facilitates the input and analysis of various generalizations of the main model. Algorithms for evaluating characteristics at two levels of the general model can be produced independently of each other, making the necessary changes.

When developing a model, first of all, it is necessary to choose the presentation form of the calculation material and determine the probabilistic characteristics that describe the principle of the operation of the call center. The term "overload" in the queuing theory corresponds to an unattended load, the flow of which has the properties of the main stream with only lower intensity $[3,4]$.
Consider the principle of distribution of excess load in a mutual assistance system. Suppose that five call centers of various capacities are combined into a system. Overload Distributor directs calls from the emergency zone to the mutual assistance system. Suppose, that the emerging stream obeys the Poisson law and is characterized by the intensity $\lambda$ emerg. Excess load from call center-emergency can be distributed among all call centers, depending on the number of operating operators in each call center. Figure 1 shows how to use the redirect method (ORR- Overflow Reroute). When any call center goes into blocking mode (all operators are busy), the ORR method is activated. Calls to this call center are routed to other call centers.

When a redirected call arrives at a call center, which is also unavailable due to the busyness of all operators or because of the management functions involved in the network, the call goes in a circular pattern to the next call center. If all call centers are not available for redirected calls, the calls is routed to an interactive voice menu. In order to get rid of direction a redirected call back to the call center, from where it was redirected, to the call center the call was transferred to, the Cancel method (Cancel Reroute Overflow) is activated. When forming a routing chain, it is necessary to take into account the features of the organization of mutual assistance, namely, the sequential nature of the transfer of redundant calls between the call centers of the chain. It is required to reduce the number of internal call redirection in the system, as well as minimize the likelihood of direction emergency calls to the IVR to reduce the stream of repeated calls. Suppose that the emerging stream obeys the Poisson law and is characterized by the intensity $\lambda$ Emerg. Excess load from call centeremergency can be distributed among all call centers depending on the number of operating operators in each call center (Fig. 1).

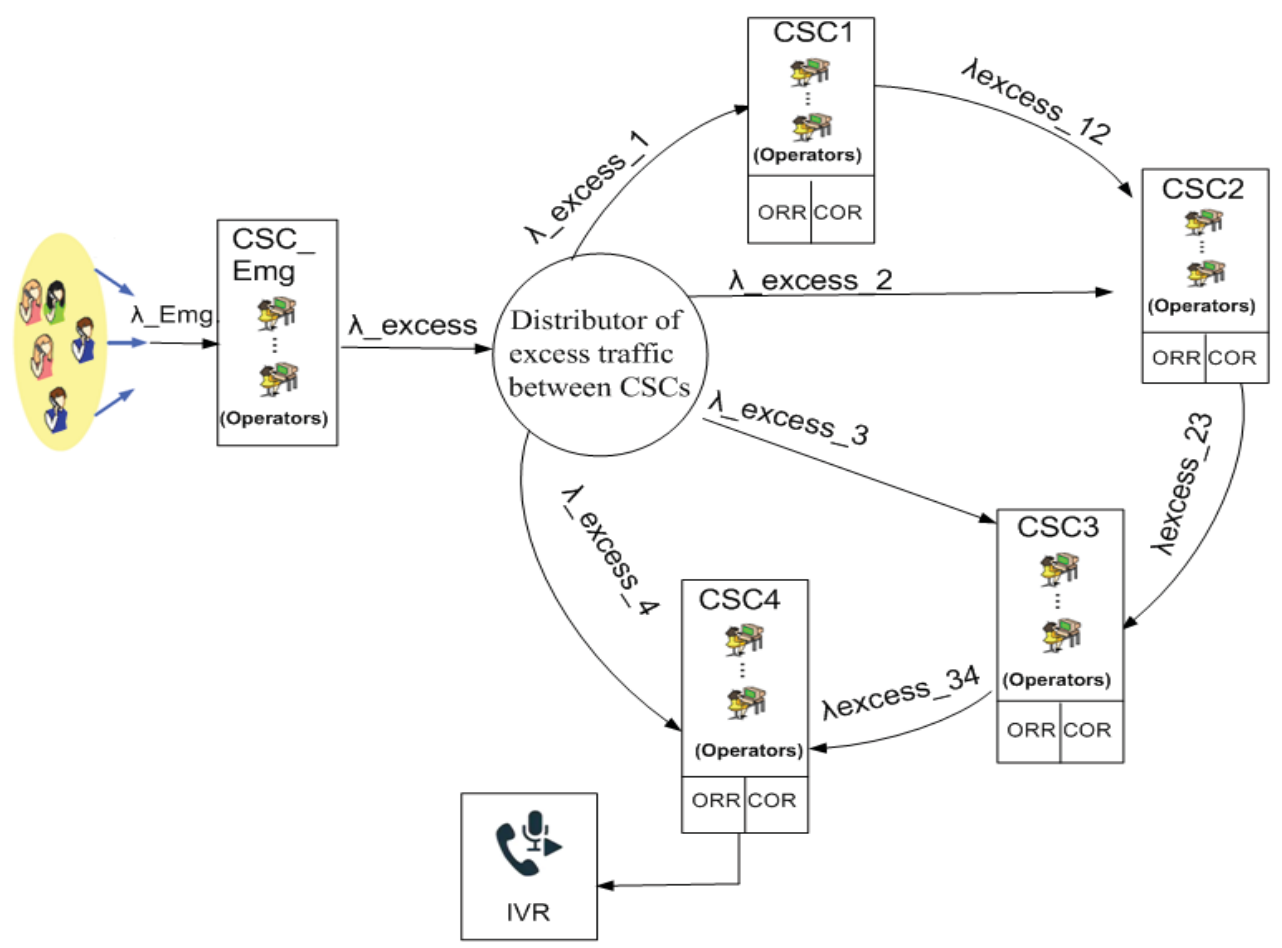

Fig. 1. A possible variant to organize call distribution using a routing chain 
Let us denote by $\lambda$ _total the total intensity of the load arriving at the $\mathrm{j}$-th call center and formed as the sum:

load with intensity $\lambda \mathrm{j}$, which is initiated by users located in the service area of this $j$-th call center;

excess load with intensity $\lambda$ excessj arriving from the call center-emergency (CSC-Emerge) at the $\mathrm{j}$-th call center

$$
\lambda \text { total }=\lambda \mathrm{j}+\lambda \text { excess } j \text {, }
$$

when $\mathrm{j}=1,2, \ldots, \mathrm{W} ; \mathrm{W}=(\mathrm{L}-1)$ - the total number of call centers to which the load from the call center-emergency can be redirected; $\mathrm{L}$ - call centers included in the mutual assistance system; $\lambda$ excessj $=\lambda$ excess $\times \mathrm{P}_{\text {Emerg } \mathrm{j}}$. When $\lambda$ excess - the total intensity of the excess load directed from the emergency zone to the mutual assistance system; $\mathrm{P}_{\text {Emerg } \mathrm{j}}-$ the probability with which the excess load is directed to the $\mathrm{j}$-th call center is determined taking into account the number of operators.

The normalization condition must be fulfilled.

$$
\sum_{j=1}^{W} \text { PEmerg } \mathrm{j}=1 \text {. }
$$

To maintain stationary equilibrium, the condition must be met:

"The intensity of the flow entering the $\mathrm{j}$-th call center, equal to the sum of the intensities of the primary call flow and the call flow directed to service from the emergency zone should not exceed the number of available operators in this call center."

Load balancing algorithms are divided into dynamic and static. To implement dynamic load balancing algorithms, operational information about the state of the system is used. In our model, this information is data on the workload of the centers, into which the transfer of calls for service from the emergency call center is possible at the time when an excess load occurs. An individual distribution (static) is possible, in which the distribution of the excess load in the call center is already predefined. Each emergency call center CSC upon arriving of citizens' appeals from the point of view of queuing theory is a queuing system of the form $\mathrm{M} / \mathrm{M} / \mathrm{V} / \mathrm{V}$. The first letter $\mathrm{M}$ means that the arriving call flows are Poisson. The second letter $\mathrm{M}$ means that the service time of calls (channel occupation) is distributed ex- ponentially. Character V shows a limited number of channel resources. And the last sign of $\mathrm{V}$ means that the call will be directed to the IVR system if all V operators are busy at the time of the call arriving. If the last symptom is not defined, then the queuing system in question describes the discipline of service with the expectation $[2,3,4]$.

Based on the program developed taking into account the possibility of transferring excess traffic between the call centers of the system, the calculation was carried out for the following options.

The mutual assistance chain combines several call centers with different bandwidths (the concept of "bandwidth" in this case is characterized by $\mathrm{Vj}$ - the number of operators in a particular call center).

The formation of a mutual assistance chain is performed in decreasing order of the capacitance $\mathrm{Vj}$, that is, call center of larger capacity are included at the beginning of the chain.

The formation of a mutual assistance chain is performed in the order of increasing capacitance $\mathrm{Vj}$, that is, lower-capacity call centers are included at the beginning of the chain.

The calculation results of the mutual assistance system that unites emergency call centers of different capacities are presented in Table 1. The following notation is introduced and used:

$\mathrm{P}_{\text {Transfer }} \quad \mathrm{CSC}_{1 \rightarrow 2}-$ the probability of transferring redundant calls from call center 1 to call center 2 ;

$\mathrm{P}_{\mathrm{ivr}} \downarrow$ last - the probability of direction emergency calls for service in the IVR of the last in the call center chain if the chain is arranged in descending order of the capacity of the operator systems;

$\mathrm{P}_{\mathrm{ivr}} \uparrow$ last - the probability of direction emergency calls for service in the IVR of the last in the call center chain, if the chain is arranged in order of increasing capacity of the operator systems.

To conduct a comparative analysis, a calculation was performed for the option presented in Fig. 2, which excludes the transfer of excess traffic between the call centers of the system. The calculation results we present in table 2 .

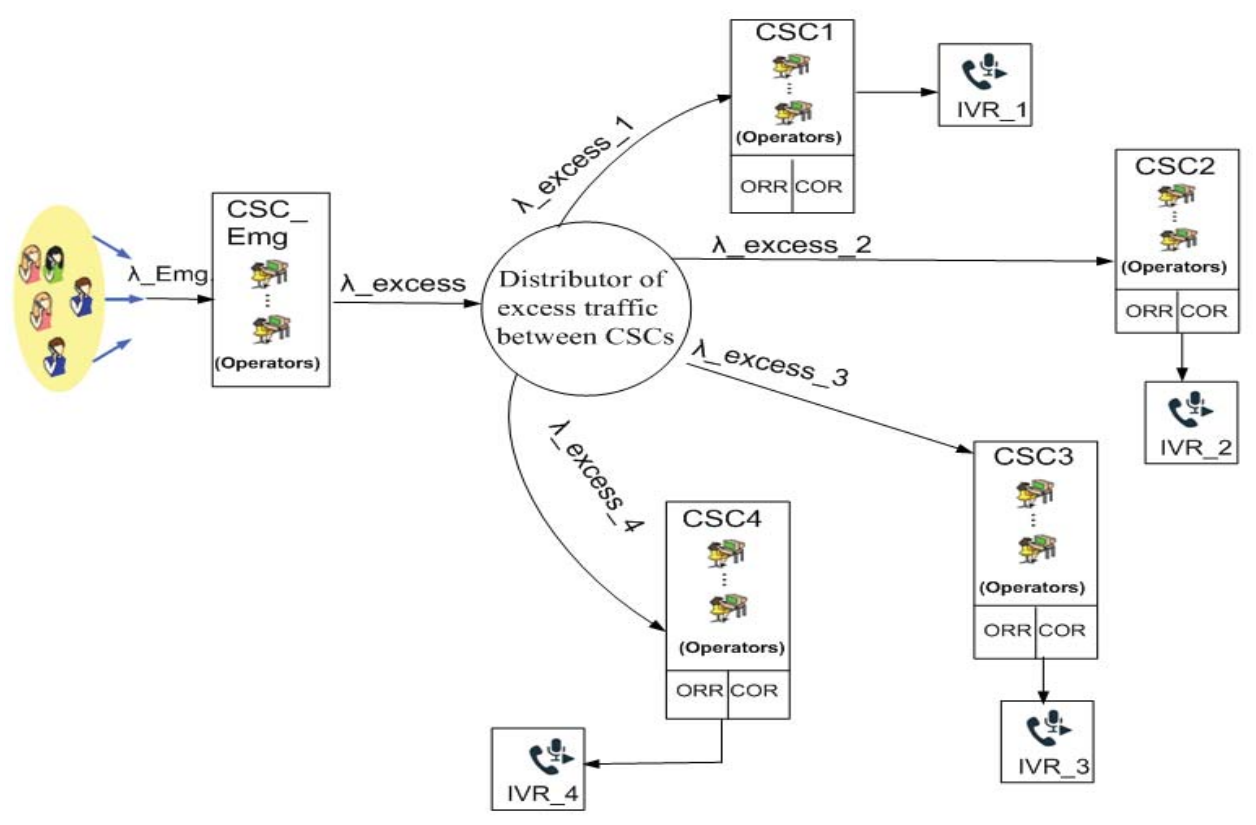

Figure 2. A promising version of the organization of mutual assistance 
Table 1

The results of calculating the probability that emergency calls from the emergency zone will be directed to serving in the IVR of the last $\mathrm{P}_{\mathrm{ivr}} \downarrow$ last call center chain (the routing chain is formed in descending order of the capacity of the operator subsystem)

\begin{tabular}{|c|c|c|c|c|}
\hline \multicolumn{5}{|c|}{ Initial data: $\mathrm{V}_{\text {Emerg }}=30 ; \mathrm{W}=4 ; \mathrm{V} 1=40 ; \mathrm{V} 2=36 ; \mathrm{V} 3=30 ; \mathrm{V} 4=24$} \\
\hline $\mathrm{A}_{\text {Emrg, }}, \mathrm{Erl}$ & $\mathrm{P}_{\text {Transfer CSC1 } \rightarrow 2}$ & $\mathrm{P}_{\text {Transfer } \mathrm{CSC} 2 \rightarrow 3}$ & $\mathrm{P}_{\text {Transfer CSC3 } \rightarrow 4}$ & $\mathrm{P}_{\text {ivr } \downarrow \text { last }}$ \\
\hline \multicolumn{5}{|c|}{$\mathrm{A} 1=\mathrm{A} 2=\mathrm{A} 3=\mathrm{A} 4=10 \mathrm{Erl}$} \\
\hline 60 & $1.7 * \mathrm{E}-05$ & 0.000109 & 0.001413 & 0.012637 \\
\hline 70 & 0.000258 & 0.000983 & 0.006159 & 0.029920 \\
\hline 80 & 0.001955 & 0.005068 & 0.018548 & 0.058406 \\
\hline \multicolumn{5}{|c|}{$\mathrm{A} 1=\mathrm{A} 2=\mathrm{A} 3=\mathrm{A} 4=15 \mathrm{Erl}$} \\
\hline 60 & 0.001041 & 0.003982 & 0.021847 & 0.081847 \\
\hline 70 & 0.005332 & 0.013939 & 0.046755 & 0.124151 \\
\hline 80 & 0.017393 & 0.035660 & 0.084553 & 0.174896 \\
\hline \multicolumn{5}{|c|}{$\mathrm{A} 1=24 \mathrm{Erl} ; \mathrm{A} 2=21.6 \mathrm{Erl} ; \mathrm{A} 3=18 \mathrm{Erl} ; \mathrm{A} 4=14.4 \mathrm{Erl}$} \\
\hline 60 & 0,039361 & 0,048571 & 0,060061 & 0,075697 \\
\hline 70 & 0,071482 & 0,089546 & 0,104827 & 0,122999 \\
\hline 80 & 0,112250 & 0,141642 & 0,161631 & 0,181313 \\
\hline
\end{tabular}

Table 2

The results of calculating the likelihood that emergency calls from the emergency zone will be directed to serving the latter in the IVR chain of the $\mathrm{P}_{\mathrm{ivr}}$ call center (the routing chain is formed in order to increase the capacity of the operator subsystems in call centers)

\begin{tabular}{|c|c|c|c|c|}
\hline \multicolumn{5}{|c|}{ Initial data: $\mathrm{W}=4 ; \mathrm{V}_{\text {Emerg }}=30 ; \mathrm{V} 1=24 ; \mathrm{V} 2=30 ; \mathrm{V} 3=36 ; \mathrm{V} 4=40$} \\
\hline $\mathrm{A}_{\text {Emrg }}, \mathrm{Erl}$ & $\mathrm{P}_{\text {Transfer } \mathrm{CSC} 1 \rightarrow 2}$ & $\mathrm{P}_{\text {TransferCSC2 } \rightarrow 3}$ & $\mathrm{P}_{\text {Transfer } \mathrm{CSC} 3 \rightarrow 4}$ & $\mathrm{P}_{\mathrm{ivr} \uparrow \text { last }}$ \\
\hline \multicolumn{5}{|c|}{$\mathrm{A} 1=\mathrm{A} 2=\mathrm{A} 3=\mathrm{A} 4=10 \mathrm{Erl}$} \\
\hline 50 & 0.0040 & 0.000204 & $5.8 * \mathrm{E}-06$ & $4,4 * \mathrm{E}-07$ \\
\hline 60 & 0.0125 & 0.001490 & 0.000109 & $1.7 * \mathrm{E}-05$ \\
\hline 70 & 0.0292 & 0.006900 & 0.001026 & 0.000260 \\
\hline 80 & 0.0548 & 0.021994 & 0.005670 & 0.002045 \\
\hline \multicolumn{5}{|c|}{$\mathrm{A} 1=\mathrm{A} 2=\mathrm{A} 3=\mathrm{A} 4=15 \mathrm{Erl}$} \\
\hline 50 & 0.0483 & 0.008857 & 0.000769 & 0.000116 \\
\hline 60 & 0.0789 & 0.025427 & 0.004353 & 0.001064 \\
\hline 70 & 0,1149 & 0,056032 & 0,016526 & 0.005803 \\
\hline 80 & 0,1536 & 0,099985 & 0,044654 & 0.021179 \\
\hline \multicolumn{5}{|c|}{$\mathrm{A} 1=14,4 \mathrm{Erl} ; \mathrm{A} 2=18 \mathrm{Erl} ; \mathrm{A} 3=21,6 \mathrm{Erl} ; \mathrm{A} 4=24 \mathrm{Erl}$} \\
\hline 50 & 0,0395 & 0,029948 & 0,021984 & 0,018005 \\
\hline 60 & 0,0679 & 0,0596643 & 0,0491394 & 0,043315 \\
\hline 70 & 0,1026 & 0,100820 & 0,0902685 & 0,083940 \\
\hline 80 & 0,1408 & 0,149797 & 0,1421396 & 0,137266 \\
\hline
\end{tabular}

The following notation is introduced and used:

$\mathrm{P}_{\mathrm{ivr} j}$ - the probability of direction emergency calls for service to the interactive voice menu of the $\mathrm{j}$-th call center of the system;

$\mathrm{P}_{\mathrm{ivr} \text { avg }}$ - the average system probability of direction emergency calls for service in the IVR of one of the call centers of the system (absence of a mutual assistance chain), which is defined as

Pivr_avg $=\sum_{\mathrm{j}=1}^{\mathrm{W}} \mathrm{k}_{\text {Emerg }} *$ Pivr $\mathrm{j}$,

$\mathrm{k}_{\text {Emerg }}$ - the proportion of redundant calls routed from the emergency call center to the call center $\mathrm{j}$.

Tables 1-3 show the calculation results for the case when call centers of different capacities are included in the system. Draw conclusions (fig. 3):

- when a call center of different capacities is included in a mutual assistance system, the sequence of placing a call center in the routing chain is essential;

- when placing call centers in decreasing order of the capacity of operator subsystems, the probability of direction emergency calls to IVR will be greatest compared to other options. Moreo- ver, it is the latter in the chain of small capacity call centers that will most negatively affect the value $\mathrm{P}_{\mathrm{ivr}} \downarrow$ last

- when placing call centers in order of increasing capacity of operator subsystems, the probability of direction emergency calls to IVR is significantly reduced compared to other options, but there is a rapid increase in $\mathrm{P}_{\mathrm{ivr}} \uparrow$ last when increasing $\mathrm{A}_{\text {Emerg. }}$.

When deploying call centers taking into account the expected average level of emergency traffic intensity inherent in a particular service area $\mathrm{Aj}$, the choice of call center capacity $\mathrm{Vj}$ can be produced taking into account the average load of operators.

The calculations performed for the values $\mathrm{Aj}=0.6 \mathrm{Vj}$ showed that it is promising to use a simpler option to implement - without additional routing of excess traffic between call centers, limiting the direction of excess traffic from the emergency zone, distributed in proportion to the capacity of the operator systems $\mathrm{Vj}$. Mathematical modeling confirmed the results of analytical calculations. 
Table 3

The results of calculating the probability that emergency calls from the emergency zone will be directed to the IVR of different call centers $\mathrm{P}_{\mathrm{ivr} j}$ and the average value of $\mathrm{P}_{\mathrm{ivr}}$ avg

\begin{tabular}{|c|c|c|c|c|c|}
\hline \multicolumn{7}{|c|}{ Initial data: $\mathrm{V}_{\text {Emerg }}=30 ; \mathrm{W}=4 ; \mathrm{V} 1=24 ; \mathrm{V} 2=30 ; \mathrm{V} 3=36 ; \mathrm{V} 4=40$} \\
\hline $\begin{array}{c}\mathrm{A}_{\text {Emrg }}, \\
\text { Erl }\end{array}$ & $\mathrm{P}_{\text {ivr1 }}$ & $\mathrm{P}_{\text {ivr2 }}$ & $\mathrm{P}_{\text {ivr3 }}$ & $\mathrm{P}_{\text {ivr4 }}$ & $\mathrm{P}_{\text {ivr_avg }}$ \\
\hline \multicolumn{7}{|c|}{$\mathrm{A} 1=\mathrm{A} 2=\mathrm{A} 3=\mathrm{A} 4=10 \mathrm{Erl}$} \\
\hline 50 & 0.0040 & 0.000200 & $5.8 * \mathrm{E}-06$ & $4,4 * \mathrm{E}-07$ & 0.000803 \\
\hline 60 & 0.0125 & 0.001412 & 0.000108 & $1.7 * \mathrm{E}-05$ & 0.002681 \\
\hline 70 & 0.0292 & 0.006121 & 0.000981 & 0.000257 & 0.007161 \\
\hline 80 & 0.0548 & 0.018029 & 0.004991 & 0.001955 & 0.016272 \\
\hline \multicolumn{7}{|c|}{$\mathrm{A} 1=\mathrm{A} 2=\mathrm{A} 3=\mathrm{A} 4=15 \mathrm{Erl}$} \\
\hline 50 & 0.0483 & 0.008043 & 0.000746 & 0.000115 & 0.011018 \\
\hline 60 & 0.0789 & 0.021569 & 0.003956 & 0.001040 & 0.020959 \\
\hline 70 & 0,1149 & 0,044801 & 0,013588 & 0.005332 & 0,036964 \\
\hline 80 & 0,1536 & 0,0767039 & 0,033148 & 0.0173932 & 0,060604 \\
\hline \multicolumn{7}{|c|}{$\mathrm{A} 1=14,4 \mathrm{Erl} ; \mathrm{A} 2=18 \mathrm{Erl} ; \mathrm{A} 3=21,6 \mathrm{Erl} ; \mathrm{A} 4=24 \mathrm{Erl}$} \\
\hline 50 & 0,0395 & 0,028433 & 0,020951 & 0,017265 & 0,024980 \\
\hline 60 & 0,0679 & 0,054331 & 0,044516 & 0,039361 & 0,049516 \\
\hline 70 & 0,1026 & 0,0881263 & 0,077321 & 0,071482 & 0,082687 \\
\hline 80 & 0,1408 & 0,126665 & 0,116021 & 0,112250 & 0,121270 \\
\hline
\end{tabular}

The method Overflow Reroute (ORR) in the emergency call system provides for the possibility of traffic redistribution in case of failure or inaccessibility of a specific call center of the system. This event can be predicted by the time between failures. If such an event occurs, then traffic redistribution is carried out for some long time. Several call centers can be excluded from the general routing chain of a mutual assistance system at the same time, while the throughput of the system will decrease [5].

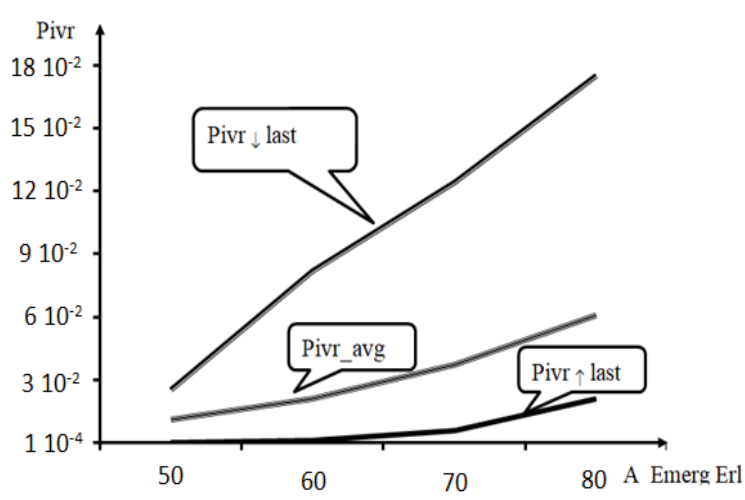

Figure 3. Dependence of the probability of direction emergency calls to IVR on the $A_{\text {Emrg }}$ value at $\mathrm{Aj}=15 \mathrm{Erl}$

Figure 4 shows an example of a call redirection implementation if initially redundant calls from a call center-emergency were distributed between four call centers $(\mathrm{W}=4)$, and then between three call centers $(\mathrm{W}=3)$. Namely, in the case under consideration, excess traffic from the call center-emergency, which was previously directed to call center3, will be distributed between call center 1 , call center 2 and call center4.

Thus, for the proposed option of organizing a mutual assistance system, it is possible to direct a significant part of the excess traffic from the emergency zone to other call centers. To distribute excess traffic, it is proposed to use a distributor that takes into account the capacity of operator systems and their working capacity.

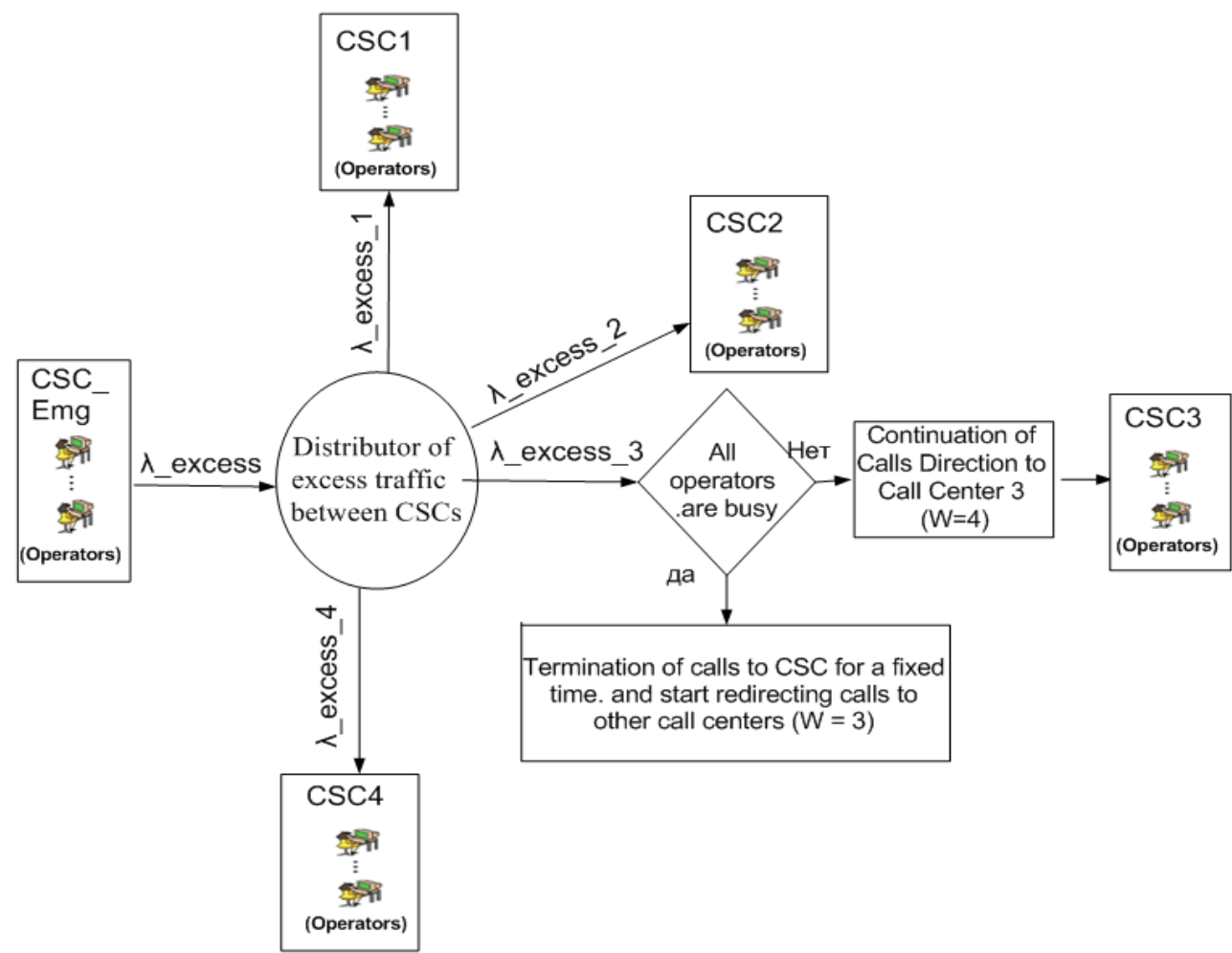

Figure 4. An example of call redirection implementation 
In many cases, it is difficult to solve problems of considerable complexity by analytical methods; in such situations, the most universal research method is the method of statistical modeling. The statistical model of the call service process is implemented in the form of a computer program.

Simulation results are used to test hypotheses and assumptions, refine empirical coefficients, and confirm the results obtained by analytical methods.

Mathematical modeling for the variant shown in fig. 2 (eliminates the re-transmission of excess traffic between call centers), confirmed the analytical calculations. As shown in Fig.5 mathematical modeling confirmed the results of analytical calculations. For modeling, we used the $\mathrm{C}$ \# programming language environment (Visual Studio 2017).

A program for modeling the emergency call service process in a mutual assistance system, the algorithm by which the program was written, and the types of generators used will be discussed in the next article. When modeling, an approximate estimate of the characteristics of the quality of service is obtained, but due to the use of special modeling methods, the required accuracy of studies is achieved [6]. The reliability of the simulation was evaluated by Student's criterion. Simulation results of the direction of emergency calls from the emergency zone will be sent to the IVR of different call centers $\mathrm{P}_{\text {ivrj }}$ and the average $\mathrm{P}_{\mathrm{ivr} \_ \text {avg }}$ values are presented in table 4 .

When modeling, the peculiarities of increasing the number of emergency calls in emergencies were taken into account. Namely, there is an avalanche-like increase in calls at one of the call centers.

The confidence interval was previously estimated. To approximate the boundaries of the confidence interval, the number of series $\mathrm{m}$ increased. For all experiments performed, the value $\mathrm{m}=40$ was chosen.

The duration of a series of tests is usually fixed, and it can be called the simulation time. Suppose that an emergency continues two hours. Based on this, the simulation time is fixed on Tmod $=$ 2 Hours. Average service time per call is set to 3 minutes.

Analysis of the results of computer simulation presented in table 4 showed, that the results of the analytical calculation of the probability that emergency calls from the emergency zone will be directed to the IVR of different call centers $P_{i_{i v} j}$ and the average value of $\mathrm{P}_{\text {ivr avg }}$ fall within the confidence interval of simulation, that is, the difference between the calculated values and the simulation data does not exceed $10 \%$ with a confidence probability 0.95 . Thus, simulation modeling confirmed the validity of analytical expressions.

Table 4

The results of modeling the direction of emergency calls from the emergency zone to the IVR of call centers $P_{i v r}$ and on average for the mutual assistance system $\mathrm{P}_{\text {ivr_avg }}$

\begin{tabular}{|c|c|c|c|c|c|}
\hline \multicolumn{6}{|c|}{$\begin{array}{c}\text { Initial data: } V_{\text {Emerg }}=30 ; \mathrm{W}=4 ; \mathrm{V} 1=24 ; \mathrm{V} 2=30 ; \mathrm{V} 3=36 ; \mathrm{V} 4=40 ; \\
\text { Tserv }=3 \text { min; Tmod }=2 \text { Hours; } \mu=20[1 / \text { Hour }]\end{array}$} \\
\hline $\begin{array}{c}\lambda_{\text {Emrg, }} \\
\text { calls per hour }\end{array}$ & $\mathrm{P}_{\mathrm{ivr} 1}$ & $\overline{\mathrm{P}_{\mathrm{ivr} 2}}$ & $\mathrm{P}_{\mathrm{ivr} 3}$ & $\mathrm{P}_{\mathrm{ivr} 4}$ & $\mathrm{P}_{\text {ivr_avg }}$ \\
\hline \multicolumn{6}{|c|}{$\lambda 1=\lambda 2=\lambda 3=\lambda 4=300$ calls per hour } \\
\hline 1000 & 0,056141 & 0,008801 & 0,000699 & 0,000942 & 0,012946 \\
\hline 1200 & 0,086106 & 0,021312 & 0,003529 & 0,001318 & 0,021193 \\
\hline 1400 & 0,118459 & 0,043572 & 0,009985 & 0,003257 & 0,033829 \\
\hline 1600 & 0,168779 & 0,070208 & 0,030148 & 0,009992 & 0,053203 \\
\hline
\end{tabular}

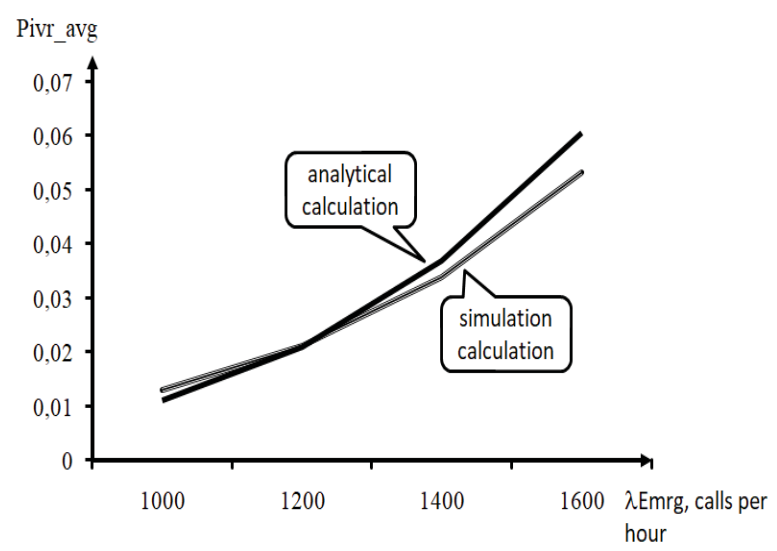

Figure 5. Dependence of the probability of direction emergency calls to IVR on the $\lambda_{\text {Emrg, }}$, calls per hour at $\lambda j=300$ calls per hour (analytical calculation and simulation calculation)

\section{Conclusions}

1. If several call centers of various capacities are included in the mutual assistance system, the sequence of their placement in the routing chain is important.

2. The probability of making emergency calls in IVR is significantly reduced when the routing chain is formed in order to increase the throughput of operator subsystems.

3. A promising way to distribute excess traffic involves the use of a distributor that takes into account the capabilities of the operator subsystems and their performance.

4. Can be used the dynamic mode of redistributing excess traffic when combining several small call centers into a mutual assistance system.

5. The method of combining call center resources into a mutual assistance system should take into account statistics on the increase in the number of emergency calls in emergencies. This is important for determining the total throughput and the number of emergency call centers included in the mutual assistance system.

6. Simulation modeling confirmed the validity of analytical expressions. It gives to the intended method of increasing throughput significant practical value.

\section{References}

1. Mohammed O.A.A. (2020). Development of approaches to ensure reliable emergency communications in emergencies. T-Comm. Vol. 14. No.1. P. 42-48. (in Russian)

2. Stepanova I.V. (2015). Use of flexible routing corporate callcenters. T-Comm. Vol. 9. No.11. P. 25-31. (in Russian)

3. Pshenichnikov A.P. (2017). Theory of Teletraffic. Textbook for high schools. Moscow: Hot line - Telecom. 212 p.

4. Stepanov S.N. (2015). Theory of teletraffic: concepts, models, applications. Moscow: Hot line - Telecom. 868 p.

5. Stepanova I.V., Ahmed Abdulvasea, Ndayinkunda Zhuven. (2015). Analysis of promising approaches to improve the reliability of converged enterprise networks. T-Comm. Vol 9. No.12. P. 44-51. (in Russian)

6. Yu. I. Ryzhikov. (2004). Simulation modeling. Theory and technology. Spb.: CROWN print; Moscow: Altex-A. 384 p. 


\title{
МЕТОД ПОВЫШЕНИЯ ПРОПУСКНОЙ СПОСОБНОСТИ СИСТЕМЫ РЕАГИРОВАНИЯ НА ЭКСТРЕННЫЕ СИТУАЦИИ
}

\author{
Мохаммед Омар Ахмед Абдулвасеа, университет Таиз, Республика Йемен; \\ МТУСИ, Москва, Россия, оmaralmu20I2@mail.ru
}

\section{Аннотация}

Основной точкой входа для всех обращений при чрезвычайных ситуациях является центр обслуживания экстренных вызовов. Общее требование - быстрая и безотказная обработка обращений граждан. Операторская система центров обслуживания вызовов рассчитана на некоторый средний уровень трафика. Резкий рост числа вызовов в чрезвычайной ситуации приводит к уменьшению доступности операторов. Только небольшая часть вызовов будет обслужена операторами. Значительная часть вызовов направляется в систему интерактивного голосового меню IVR. Могут быть пропущены важные сообщения о развитии чрезвычайной ситуации. Рассматриваются варианты создания системы взаимопомощи для своевременного получения достоверной информации от пользователей. Результаты аналитических расчетов подтверждены результатами математического моделирования.

Ключевые слова: режим чрезвычайной ситуации, экстренные службы, интерактивное голосовое меню, центры обслуживания вызовов, пропускная способность.

\section{Литература}

І. Абдулвасеа М.О.А. Подходы к обеспечению надежной экстренной связи в условиях чрезвычайных ситуаций (на англ. языке/ М.О.А. Абдулвасеа // Т-Сотm: Телекоммуникации и транспорт. 2020. Том I4. №І. С. 42-48.

2. Степанова И.В. Использование средств гибкой маршрутизации в корпоративных центрах обслуживания вызовов // Т-Сотт:

Телекоммуникации и транспорт. Том 9. 20I5. №ІІ. С. 25-3І.

3. Пшеничников А.П. Теория телетрафика. Учебник для вузов. М.: Горячая линия - Телеком, 2017. 212 с.

4. Степанов С.Н. Теория телетрафика: концепции, модели, приложения. М.: Горячая линия - Телеком, 20I5. 868 с.

5. Степанова И.В., Мохаммед Омар Ахмед Абдулвасеа, Ндайинкунда Жувен. Анализ перспективных подходов к повышению надежности конвергентных корпоративных сетей связи. Т-Сотm: Телекоммуникации и транспорт. Том 9. 20I5. №12. С. 44-5I. 6. Рыжиков Ю.И. Имитационное моделирование. Теория и технологии. Спб.: КОРОНА принт; М.: Альтекс-А, 2004.384 с.

\footnotetext{
Информация об авторе:

Мохаммед Омар Ахмед Абдулвасеа, университет Таиз, Республика Йемен; аспирант кафедры Сети связи и системы коммутации МТУСИ, Москва
} 